\title{
Optimum Choice for Areas of Sustainable Development in the Province of AL-Qadisiyah
}

\author{
Haider Aboud Gizar AL-Shammari \\ Department of Geography, Faculty of Arts, University of AL-Qadisiyah-AL-Diwaniyah City 58000, Iraq
}

\begin{abstract}
The optimization of the selection process for the areas of sustainable development in Diwaniyah province on a set of steps and ideas of multiple is relying on what is characteristic of that region of the variety available and the potential of geographic. They turn the potential of the underlying sustainable development. There are several ways to choose the most suitable of those places, including the threshold of marginal environmental (UET), which in turn on a number of steps, and when adopted in the study area appeared a range of places that fit the desired goal.
\end{abstract}

Key words: Development, sustainable development, AL-Qadisiyah.

\section{Introduction}

Providing most of the economic institutions in undertaking the establishment of development projects to study the environmental impact $\left(^{*}\right)$ for such projects under what is known as the feasibility study, has been adopted this concept at the international level in 1987 and then came Agreement (Alaespo) on transboundary impacts in the year 1991, to emphasize the need for a study of the environmental impact in all countries of the world, without exception. And requiring a transition to a more sustainable and environmentally friendly economy and a more comprehensive social is re-directing the growth in all sectors to ensure an equal amount of importance of economic, social and environmental dimensions when determining the objectives. The selection of the technical designs and technology and ways of operating the most environmentally friendly, as well as the selection of

$\left(^{*}\right)$ The environmental impact: a study on the projects of predictive or developmental activities of the impact of potential environmental to determine the alternatives available to assess the environmental impact of choosing the best alternatives influences negative at least the choice of means of alleviating them.For more information see:

Salah al-Hajjar, the environmental impact of industrial projects and development guide, Dar Al Nahda for printing, publishing and distribution, Cairo.2002.

Corresponding author: Haider Aboud AL-Karaawi, Ph.D., research field: development geography. appropriate projects to environmental conditions sites, achieves so many benefits, including reducing the cost of treatment of pollutants and to optimize the use of resources and the rationalization of water and electricity and maintain the aesthetic aspects of the projects consumption. And in the process a great choice for areas of sustainable development in Diwaniyah province on a set of steps and ideas of multiple is relying on what is characteristic of that region from a variety of geographical potentials which in turn potential underlying development, which in turn are divided into four groups, including the availability of water resources and arable land, and provide energy sources and it provides investment.

\subsection{Research Problem}

How can we put the system to determine the best sites for sustainable development activities in AL-Qadisiyah province?

\subsection{Research Hypothesis}

The basic idea of this system in two steps, first determines the potential for development and is divided into four groups are the availability of water resources and provide safe development of the land and the availability of energy sources and availability of 
investments, while the second plan is to identify the potential function uses size and distribution based on the potential of the site and the requirements of the proposed development .

\subsection{Research Importance}

The importance of research is to find a system to determine the best suited for development, development and avoid the mistakes that cost a lot of money, effort and time place.

\subsection{Research Goals}

- Detection of obstacles imposed by the geographical reality of direct and indirect effects in the process of implementing the plan;

- Reduce the economic losses caused by the direct environmental damage;

- Maintain the continuity and sustainability of natural resources and their importance to the stability of the economic activity of the population;

- Preservation of the environment and its components and contribute to halt deterioration in a way that will raise the living standards of the population;

- Support efforts to prevent the transmission of environmental pollutants between states and the preservation of local, regional and global environment.

\subsection{Research Approach}

Researcher at the descriptive analytical method which is used heavily in development studies adopted has proved a great addressing the problem of search and access to good results.

\subsection{Boundaries of the Study Area}

Extending the study on an area of the region is estimated at $\left(8,153 \mathrm{~km}^{2}\right)$ and includes Diwaniyah province Bagdatha four (of Diwaniyah, Afak and Hamzah and Levantine) and its environs eleven, and was characterized by its location average of the Central Euphrates provinces and geographic proximity to the most important cities and urban centers in the region (Fig. 1).

1.6.1 Firstly-The Environmental Dimension in the Planning Process

The changes in the curricula of the planning of most of the countries of the world in the last 30 years have been the introduction of environmental considerations in these curricula through the adoption of the precautionary principle (Precautionary Principle) as the basis of the foundations for good governance and a means to deal with environmental problems, the fact that one of the most important reasons for planning is to avert the dangers prevention before they occur, as well as for other reasons relating to solve problems and reduce the contradictions become strategies and development plans more tekaya to preserve the environment [1].

Summarized environmental dimensions of development planning and sustainable in the study of the total area of the thoughtful region and conducting a comprehensive survey and then to determinethe optimal use of them, usually start this type of planning divide lands depending on their power of agriculture, for example, and preventing the establishment of any activities or other activities contaminated and harmful to the environment, taking into account the trends of the prevailing winds and geographical proximity to water resources and the protection of arable land from any side effects expected in the future to study the environmental effects of Ref. [2].

It assesses the environmental effects of developmental projects as one of the Contemporary mecha-nisms modern strategies which would guarantee the achievement of the desired balance between envi-ronment and development. One of the pillars of the success of the environmental planning and sustainable, and has reached many studies and research organization to a series of steps, whereby the planning process for sustainable development, the Chairperson of the systems aimed at the integration of the environmental dimension in the planning process, 
including the system of marginal threshold environmental Ultimate Environmental Threshold (UET).

Which is one of the methods used in the planning of land uses and the introduction of an environmental dimension and is an integral part of the planning process for the purpose of which is to know the adverse effects on the environment of the proposed development and to try to prevent damage to the accompanying and relies on the assessment of the prospects for development and environmentally sound through knowledge of the borders before the severe pressures on the environment, in order to continue the development that should be the dimensions of these borders causing harm to the environment [3].

Environmental regulations natural potential limited capacities and to accept the variables that will change without deterioration, if this potential, the prospects for the deterioration become negative effects are, I and addressees. Apply this approach to the activities and events to different developmentit applied to agriculture, industry and housing, tourism, transport and communications, as well as the applicable to the rural areas, taking into account the inputs of planning the ecological, social, economic and technical cooperation, which is the essence of sustainable development [4].

1.6.2 Secondly-Environmental Threshold Limit (UET)

It is the system working on the introduction of the environmental dimension in the organization uses different ground, one of the parts complementary development process, in order to identify the negative side effects caused by them, through the assessment of Amkant development environmentally determine the limits of the stress that is given ecosystem, so that after this border intimidated and $\mathrm{N}$ to return to its natural

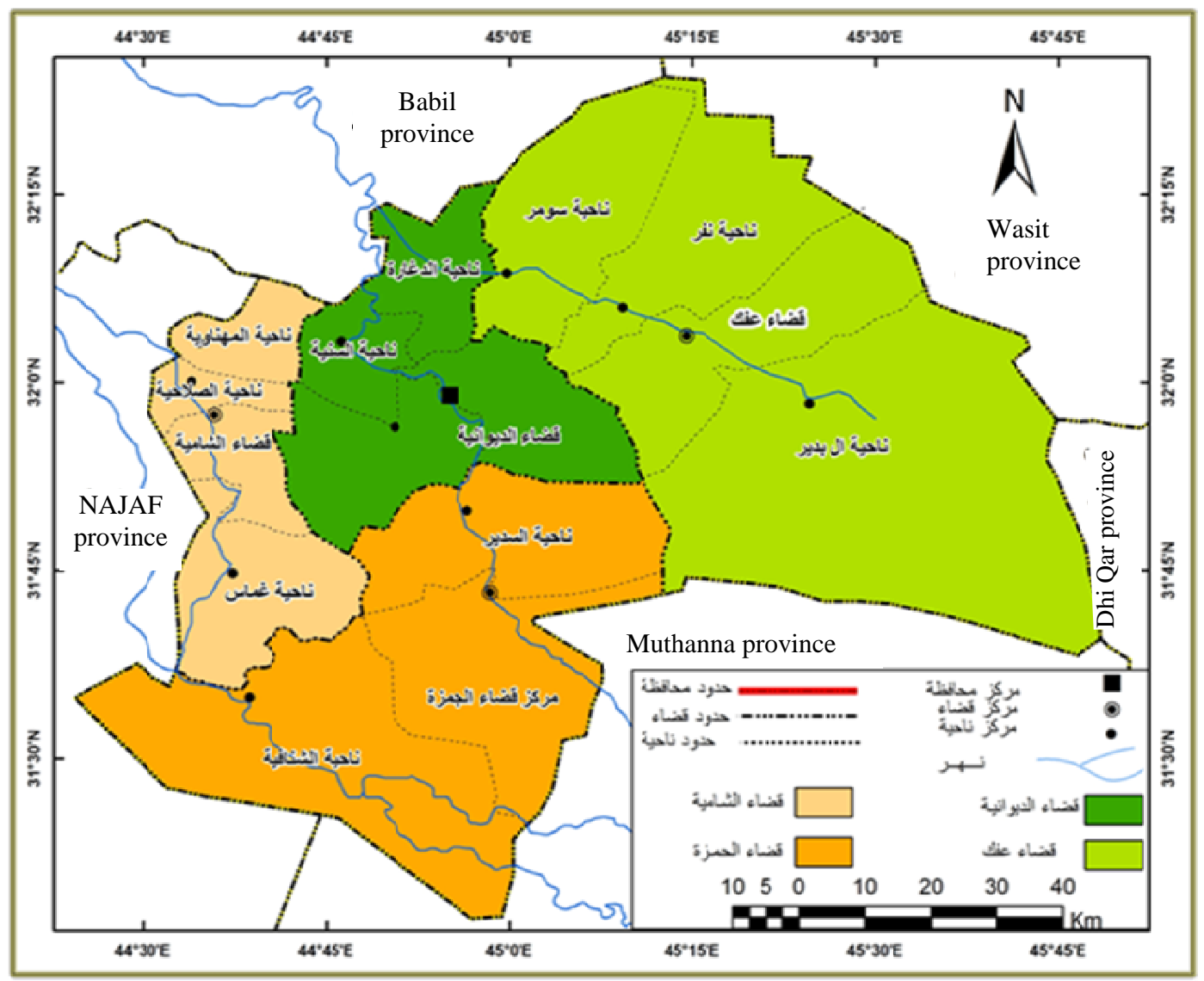

Fig. 1 Geographical location and astronomer of the study area.

Source: based onresearcher: General Authority of Survey, Qadisiyah province administrative map scale of 1: 1,500,000, Baghdad, 2012. 
state and the previous balance [5]. To this threshold are four main dimensions:

- The proposed development site, in the study of the geographical reality and potential in the maximum marginal bearing signs of development;

- Development at the local or regional level scale, national or global;

- Type of development, whether industrial or agricultural development, political or housing, etc.;

- Development time, any development on the immediate term plan or a short, medium or long-term effects and the resulting [6].

The benefits realized from behind this measure are to determine the appropriate and proper gap, for various types of development proposed or anticipated presence in an area so vital to maintain the balance of the natural environment and to environmentally sensitive areas, while maintaining the quality of air, water and coordination sites (landscaping). It is also securing its goals surest possible occurrence of natural hazards in the proposed development area protection, and Table 1 , approach the work of the environmental threshold limit (UET) and how it is done in three steps stages of any development project.

\subsubsection{Thirdly}

Approach to the work of modern environmental threshold (UET) in land use planning for sustainable development:

The first stage: preliminary studies

Including knowledge of the objectives of the proposed development and the field of application and assumptions [7], which are required for the proposed information application development area where, for example, when evaluating the study area, which includes the city of Diwaniya, which has a population of 403,678 persons in 2015. Most of them work in agriculture and grazing, but because of poor management and the use of technology, agricultural crops have been decreasing each year and increasing desertification and prevent land use significantly, causing the erosion of agricultural areas that go along with the presence of aesthetic view areas by having

Table 1 Modern approach to the work of the environmental threshold (UET).

\begin{tabular}{|c|c|c|}
\hline \multicolumn{3}{|c|}{ Preliminary studies } \\
\hline Hypotheses & Knowledge goals & Application area \\
\hline \multicolumn{3}{|c|}{ Subject development } \\
\hline Industrial and tourism development & Agricultural development and grazing & Housing \& entertainment \\
\hline \multicolumn{3}{|c|}{ Data and information collection } \\
\hline \multicolumn{3}{|c|}{$\begin{array}{c}\text { The second stage } \\
\text { Potential environmental threats }\end{array}$} \\
\hline \multicolumn{3}{|c|}{ Resources relationship with activities } \\
\hline \multicolumn{3}{|c|}{ Potential environmental threats } \\
\hline \multicolumn{3}{|c|}{ Resources are at risk } \\
\hline Forests & Livestock & Terrain and landscapes \\
\hline \multicolumn{3}{|c|}{$\begin{array}{c}\text { The third stage } \\
\text { Thresholds and selection of appropriate blanks development }\end{array}$} \\
\hline Resistance & Biological significance & Transformation and uniqueness \\
\hline \multicolumn{3}{|c|}{ Put the norms (UET) } \\
\hline \multicolumn{3}{|c|}{ Determination (UET) } \\
\hline \multicolumn{3}{|c|}{ Choose environmentally appropriate vacuum for each of the } \\
\hline Agriculture and grazing & $\begin{array}{c}\text { Tourism development is low and } \\
\text { Entertainment }\end{array}$ & High concentration of population \\
\hline \multicolumn{3}{|c|}{$\begin{array}{c}\text { The fourth stage } \\
\text { Interpretation and analysis }\end{array}$} \\
\hline
\end{tabular}

Source: researcher depending on: www.moma.gov. 
some physical manifestations. Preliminary study suggested a review of current practice of economic policy, and guide the future development of the region in a way (UET), as follows Preliminary study suggested a review of current practice of economic policy, and guide the future development of the region in a way (UET), as follows:

- Proposal for sustainable agricultural development based on the strategy set by the competent authorities, of its priorities the provision of health food and sound development of the sons of the study area first and increased the need can be exported to other governorates and even outside Iraq, especially that the study area is famous for its unique collection of crops with quality local and international cuisine, as Rice (Amber);

- Proposal high population development to meet the large increase in developments from the countryside to the city, immigration, and that flow towards areas where more jobs are available from the countryside;

- Propose a sustainable tourism development, which will inevitably grow and expand through the presence of many of the sites and attractions scattered in most areas of the study area [8].

The second stage: the potential environmental threats

Increased threats to the environment in recent times, after the climatic changes of the many and their effects, other threats have emerged are through the expansion of development projects on agricultural expense of the environment and transform large parts of agricultural land to other uses of residential and commercial, especially in the study area. Therefore, there is an urgent need to study the relationship of natural resources with development activities, and a statement of potential such as environmental threats and analyze prone to natural resources at risk from water and natural surface resources and the preservation of the landscape [9], a phase takes place in four main steps combine these threats:

Step one: analysis of relationships in natural resources development activities and what is the role of development activity in which, if a basic in its dependence on resources, or the role of reinforcing or junk, or conflicting and is not compatible with the natural resources;

Step two: an example of the side-effects of development (important cannot be avoided or important can be canceled or unimportant);

Step three: an example of the sensitivity of the resources as a result of side effects of development are they high, medium or non-existent or non-significant;

Step four: the analysis of the potential consequences for development [10].

1.6.4 Fourthly-Mechanisms to Choose the Candidate Sites

Subject to the process of selection of the best sites of the group of considerations and perhaps in the forefront of the evaluation process, which is separate from the economic feasibility study or within the framework of the technical feasibility study of the project, the evaluation process is according to the type of project and size but there is a framework for this evaluation and:

- Site selection and the extent of environmentally fits with projects and the activities surrounding it;

- Carrying environmental systems surrounding the site expected loads of pollutants resulting from projects;

- The health effects of long-term, resulting from the establishment of the project;

- The effects of the project on the economic and social development;

- Availability of basic infrastructure in the project site and the implications of the availability of basic rate on site;

- Pollutants resulting from the operations of the various industrial and ways to deal with these pollutants to preserve the health of the workers of the property and the neighboring areas of industrial and agricultural and demographic [11].

The plan can be through dynamic analysis which 
constitutes the economic activities and configures determining them absolute and the border and sketches based on the basics that configuration can be classification on the basis of many are:

(1) Classification on the basis of the place, location refers to the classification on the basis of the spatial dimension and the availability of the terms of reference to which they relate to the size of the resources available, whether natural or human;

(2) Classification on the basis of qualitative specialization, classification means the institutions of economic activities, depending on the type of the function.

All this gives the flexibility in the development plans of space, accordingly, were divided into the study of economic activities in the region and thoughtful to:

- The first production is intended to agricultural activity;

- The second production is intended production adopted on industrial production processes;

- The third production of this section includes what might be called the service sector, whether infrastructure or the commercial sector or tourism [12].

1.6.5 Fifthly—Determine the Spatial Dimension of Sustainable Development in the Study Area

This is done by analysing the relations between various sectors and that there should be a balanced development, including with the preservation of the ecological balance, according to the data available in the region studied the study suggested that there are several candidate regions to develop the areas of sustainable development according to certain considerations are:

- The continued the environment in which found him, in the sense that the use of the natural resources within the capacity of the environment to produce alternative non-renewable resources;

- Regeneration and is intended to be the use of renewable resources within the limits of their ability to regenerate again;

- The instability: the lack of change in the sights of the environment, including making it unable to regain its balance;

- Purity: the environment clean keep what remained unable to absorb their feces where he received;

- Balanced growth, which is one of the most important manifestations of environmental balance [13].

\section{Sustainable Development of Water Resources}

It was the choice of the marshlands that spread and distributed in different areas of the study area, the threat posed by these environment unique biodiversity and environment exposed to many threats by the population nature itself. It is also ideal for a natural reserve maintain animal species endangered species, and one of the most important of those of the marshes and the agenda [2].

It should take the sustainable development of the marshes into account the need to manage and achieve a balance between the benefits derived from ecosystems, so there should be an administrative effort under way in a good understanding of the value of the services provided to the ecological system and trade-offs associated with the political options available. And the political decisions taken should address the differentiation between uses and future current and projected the lagoons, these include differentiation of special importance between agricultural production and the quality of water use, land use and biological diversity and the development of water use and the variety of aquatic life.

\section{Sustainable Rural Development}

Aimed at sustainable rural development to provide sustainable livelihoods in various economic, social, ecological and agricultural rural areas, in order to eradicate poverty and to increase the empowerment of people living in poverty and increase their access to productive resources and services, public institutions and private land, jobs, education, health. It is also the 
Table 2 The most important marshes in the study area.

\begin{tabular}{|c|c|c|c|c|c|}
\hline $\begin{array}{l}\text { Area } \\
\mathrm{km}^{2}\end{array}$ & Location & Attention and follow-up & Evaluation and studies & The description & Marsh name \\
\hline 20,000 & $\begin{array}{l}\text { The } \\
\text { northeastern } \\
\text { part }\end{array}$ & $\begin{array}{l}\text { Decrease and lack of } \\
\text { control on the amounts of } \\
\text { flooding from the Tigris } \\
\text { and the expansion of } \\
\text { agriculture. }\end{array}$ & \multirow[t]{2}{*}{$\begin{array}{l}\text { Ramsar List reported on } \\
\text { the basis accommodate } \\
\text { nearly } 20,000 \text { water } \\
\text { birds during the winter. }\end{array}$} & $\begin{array}{l}\text { Marsh large insulated located to the } \\
\text { south of the Tigris River and } \\
\text { approximate distance of } 35 \text { kilometers } \\
\text { south-west of Kut, } 65 \text { kilometers } \\
\text { north-east of Diwaniyah. Feed from } \\
\text { overflowing irrigation canal, as well } \\
\text { as the flood waters of the Tigris River } \\
\text { water. About 100,000 hectar. }\end{array}$ & Marsh Aldhelm \\
\hline 10,000 & $\begin{array}{l}\text { West of the } \\
\text { study area }\end{array}$ & $\begin{array}{l}\text { Decrease in the flow of } \\
\text { the Euphrates River, } \\
\text { sewage problems, and } \\
\text { continued hunting. }\end{array}$ & & $\begin{array}{l}\text { The seasonal freshwater lake located } \\
\text { about } 10 \text { kilometers east of the } \\
\text { Euphrates River, } 35 \text { kilometers to the } \\
\text { west and south-west of Diwaniyah. } \\
\text { About } 10,000 \text { hectares. }\end{array}$ & $\begin{array}{l}\text { Marsh of Abn } \\
\text { Nagem }\end{array}$ \\
\hline 2,000 & & \begin{tabular}{|l|} 
"Third River" runs \\
through the region, and \\
the expansion of irrigated \\
agriculture and sewage \\
problems.
\end{tabular} & $\begin{array}{l}\text { Ramsar List reported on } \\
\text { the basis accommodate } \\
\text { nearly } 20,000 \text { water } \\
\text { birds during the winter. }\end{array}$ & $\begin{array}{l}\text { It is one of the small and seasonal } \\
\text { water bodies along the almost } 125 \\
\text { kilometers and is situated between Kut } \\
\text { and Shatra about } 100 \text { kilometers east } \\
\text { of Diwaniyah. }\end{array}$ & Shatt al-Gharraf \\
\hline 4,000 & & $\begin{array}{l}\text { Decrease in the flow of } \\
\text { the Euphrates River, and } \\
\text { the expansion of } \\
\text { agriculture, construction, } \\
\text { sewage problems and slit } \\
\text { channels. }\end{array}$ & $\begin{array}{l}\text { Ramsar List reported on } \\
\text { the basis accommodate } \\
\text { nearly } 20,000 \text { water } \\
\text { birds during the winter. }\end{array}$ & $\begin{array}{l}\text { Isolated and stand a distance of } 5 \\
\text { kilometers north of the Euphrates } \\
\text { River, and a distance of } 80 \text { kilometers } \\
\text { to the west and north-west of } \\
\text { Nasiriyah and about } 85 \text { kilometers to } \\
\text { the south and south-east of } \\
\text { Diwaniyah. Nehrlafrat floods fed by } \\
\text { water. }\end{array}$ & Marsh of Lafta \\
\hline
\end{tabular}

sustainable rural development which is a key strategy for the development of rural areas to achieve economic and social welfare, and the composition of the basic rule through the preservation of the environment and natural resources in the countryside, which does not mean that such development projects in the productive and service only, but also means coordination and so that the output of these projects inputs for other projects. Hence the importance of sustainable rural development is in fundamental changes in social relations and participates in the construction and management of the community and Changing Social Awareness. Since this type of development means the long-term sustainability of production and consumption in relation to all economic activities for access to the use of available resources (renewable and non-renewable resources), optimal use and management of the Rashid in order to satisfy the needs of different human is depending on the development of agriculture and the preservation of the environment and the protection of natural resources to meet the human needs of the developmental and environmental needs of present and future generations [13].

Since the rural areas constitute the vast majority of the study area since rate (50\%), so the development of this part of the land of the study area would no doubt create a group from the centers of growth and transformation in the paths of development and establishes beyond this stage, but face considerable challenges in the forefront of the retreating performance barnyard of the agricultural sector in the areas of production and employment generation, housing, inappropriate and lack of infrastructure.

\section{Sustainable Tourism Development}

Representing a strong and sustained rise of tourism activity in recent decades, one of the most important economic, social and cultural phenomena at the present time, tourism has recently begun to occupy a prominent place in many of the sustainable 
development strategies of developing countries. Among the items on the agenda of many international conferences on sustainable development, the aim of sustainable tourism in essence to protect local culture and environmental characteristics and rationalizing the use of tourism resources and protection of the environment from pollution, who accompanies the tourist activity in all bone [14]. Due to link tourism viable natural and human well-known attractions, so the selection of sites for the development of sustainable tourism will be linked undoubtedly those sites which range from archaeological sites that are spread in a variety of locations in the study area, the most prominent city Niebuhr archaeological and Essen, and the hills of luna and Alsdom and other sites candidate. But in need of studies new expedition, there is also a religious sight known at different levels of local, regional and even global, including the Imam Ali mosque eastern Hamsa abu credit other sacrilege. There is also the possibility of the establishment of tourist villages associated with the nearby areas of watercourses and the integration of land uses and ad hoc social development programs ahead with not to neglect the economic dimension which provides opportunities for investment attraction tourist projects.

\section{Housing Development Sustainable Development}

It has been signed difference between economists as they work to consolidate the so-called general objectives of Housing, and this difference occurred, including detail on the Millennium President, but the sustainability of housing emphasizes the following:

- Formation of integrated communities by emphasizing the concept of residential group, not solo to find spaces of the building led to social relations;

- Emphasis on micro-climate change adaptation with the natural environment;

- Emphasis on open spaces small and shaded spheres;

- The development of communities and rehabilitation;

- Constitute the residential cities as the nucleus of attracting development contribute to urban extension with emphasis on urban identity of the city [15].

Intersects the housing sector closely intertwined with all areas of sustainable development aimed at improving the quality of life of individuals as the first step to improve the quality of life for the stability of them and a healthy environment secure and equipped with basic services. The basis for achieving sustainable development in its broadest sense through housing depends on the achievement of the principle of complementarity in the urban policies. That includes all of the elements of the economically, socially and environmentally sustainable development to be implemented under the action strategies within the rational management of integrated, raising the efficiency of the city to compete with the rest of the cities.

Reflect housing sustainability on the situation of balance and the drafting of the determinants of environmental objectives, economic, social and even political in cities, the sustainability of natural resources and sustainability of the technical and economic and social development. This aspect has taken exceptional and special attention, given the inability of many countries in the developing world to meet the goals of urban sustainability comprehensive concept. There are two indicators linked to the housing issues that are social indicators which are measured by population growth rates and migration, fertility and institutional indicators, measured by the ratio of the urban population and housing and non-formal education (Random Play) and space devoted to housing for everyone and the price of housing projected income [16].

In view of the prevalence of cities in most parts of the study area, therefore, one of the most ideal characteristics of housing strategy for sustainable development and that those cities the nucleus of the Strategy. With interest the rural housing which 
represents Emad strategy being limiting migration processes from the countryside to the city and relieves the burdens on the planners and infrastructure that suffer from the dilapidated facilities in the study area.

\section{Conclusion}

Facing the planning process for the sustainable development of a set of internal and external challenges can be summarized as follows:

- The lack of experience and skills and qualified human resources capable of leadership and oversight of the planning process;

- The lack of environmental institutions to help the planning process and leadership oriented;

- Conflict of goals and orientations and the lack of clarity and lack of realism often opposes the policies and curricula;

- Drawing plans and strategies without the existence of a real and effective between the various economic sectors partnership;

- The absence of regulations held accountable or monitor the plans and projects for the stomach for implementation.

\section{Recommendations}

- The urgent need for the establishment of an institutional environment address planning process for sustainable development in the study area;

- The unification of the objectives and opposes the policies established clarity as efficient and effective;

- True partnership between all economic sectors and between the public and private sectors, pushing the wheel of creativity and initiative;

- Addressing the problems afflicting the currently community and continuously, instead of going to the problems of the far-reaching and seriously in the present time;

- Address the problems currently afflicting society continuously instead of going to far-reaching and serious problems at the present time;
- Take advantage of the feedback to the development process of sustainable development in a healthy and sound;

- Attention to sustainable human development and working in the areas of planning and sustainable development and the development of capacities and potentials of leadership and scientific;

- Use of modern methods of development planning and the use of modeling houses of global experience in the field of sustainable development planning and successful models of development;

- The development of research centers and attention to studies and research in the areas of various development;

- The intensification of links between the various government agencies and increase coordination among them in the preparation and implementation of development plans.

\section{References}

[1] Mohammad, al-Anbari. 2011. "Include a Shift in the Curricula of Planning for the Countries of the World toward a Planning and Environmental Development Magazine.” Faculty of Engineering: 2.

[2] Mustafa Jalil Ibrahim. 2011. "The Impact of the Spatial Characteristics in Mechanisms for Development Magazine.” The Faculty of Arts 102: 715.

[3] Mohammed Abu al-Qasem Mohamed. 2005. “Environmental Management Systems.” Assiut Magazine of Environmental Studies 29: 22.

[4] Mohammed Ali al-Anbari, op. Cit., P. 3.

[5] Mustafa Jalil Ibrahim al-Zubaidi, and Ammar Khalil Ibrahim al-Zubaidi. 2009. "The Impact of the Environment on the Economies of the Spatial Signature of Investment Projects.” The Fifth Scientific Conference, the Higher Institute of Urban and Regional Planning for Graduate Studies, 11.

[6] Mamdouh Ahmed Morsi. 2008. “Environmental Management to Assess the Environmental Impact of Projects.” Assiut Journal of Environmental Studies 32: 107.

[7] Noureddine Hormuz. 2006. "Tourism and Tourism Development Planning.” Tishreen University Journal for Studies and Scientific Research (a series of economic and legal sciences) 28 (3): 15.

[8] Amina Monastery. 2014. "The Impact of Environmental Threats to the Reality of Human Security in Africa." 
Master unpublished, submitted to the Faculty of Law and Political Science, University of Mohammed Khider, 32.

[9] The United Nations Development Group. 2009. The Integration of Environmental Sustainability in the Country Analysis and the United Nations Development Assistance Framework, 4.

[10] Mustafa Jalil Ibrahim al-Zubaidi, Ammar Khalil Ibrahim al-Zubaidi op. Cit. p. 6.

[11] Khaled Mohamed Fahmy. 1988. "Industrial Resettlement and the Environment." The Institute of National Planning, Egypt: 44.

[12] Ousserir Munawar and Ben Hadj Djilali Maqraoy Fethiye. 2012. "Environmental Feasibility Study for Investment Projects.” The Economies of North Africa Journal 7: 335.

[13] League of Arab States and the Arab Organization for
Agricultural Development. 1998. "Strengthening the Role of Agricultural Cooperatives in Achieving Sustainable Rural Development.” Khartoum, Sudan, 20.

[14] Howaidy Abdul Jalil. 2014. "Interactive Relationship between Eco-Tourism and Sustainable Development.” Journal of Social Studies and Research 9: 223.

[15] Bosuharh Nazir and Abdul Razzaq Salam. 2012. "Prospects for Sustainable Housing Development in the Arab Countries.” The Forum Countries about the Housing Crisis in the Arab Countries and the Prospects of Reality, Algeria, 10.

[16] Solomon Muhanna Rueda Depp. 2009. "Planning for Sustainable Development.” Damascus University Journal 25 (1): 1.

[17] www.moma.gov. 